\title{
Role of Double Metal Cyanides in Chemical Evolution: Interaction of Ribose Nucelotides with Metal Hexacyanocobaltate(III)
}

\author{
Rachana $\mathbf{S}^{1}$, Anand Kumar ${ }^{2}$, Asif Iqubal Md1 and Kamaluddin ${ }^{1^{*}}$ \\ ${ }^{1}$ Department of Chemistry, Indian Institute of Technology Roorkee, Roorkee-247667 UttaraKhand, India \\ ${ }^{2}$ Department of Chemistry, Dr. B. R. Ambedkar National Institute of Technology Jalandhar, Punjab-144011, India
}

*Corresponding author: Kamaluddin, Department of Chemistry, Indian Institute of Technology Roorkee, Roorkee-247667 Uttara Khand, India, Tel: +91-1332-285796; E-mail: kamalfcy@iitr.ac.in

Rec date: Aug 01, 2015; Acc date: Aug 14, 2015; Pub date: Aug 18, 2015

Copyright: $\odot 2015$ Rachana S, et al. This is an open-access article distributed under the terms of the Creative Commons Attribution License, which permits unrestricted use, distribution, and reproduction in any medium, provided the original author and source are credited.

\begin{abstract}
Based on the hypothesis on the presence of double metal cyanides in the primeval seas and their role as prebiotic catalyst, adsorption of RNA components, 5'-GMP, 5'-AMP, 5'-CMP and 5'-UMP on metal(II) hexacyanocobaltate(III) (MHCCo; $\mathrm{M}=\mathrm{Mn}, \mathrm{Fe}, \mathrm{Ni}, \mathrm{Zn}$ ) has been investigated. The adsorption data obtained at neutral $\mathrm{pH}$ were found to follow Langmuir adsorption in the concentration range $1.0 \times 10^{-4} \mathrm{M}$ to $3.0 \times 10^{-4} \mathrm{M}$. The value of Langmuir constants, $\mathrm{Xm}$ and $\mathrm{KL}$ were calculated from the slope and intercept of the respective isotherms. On the basis of infrared (IR) spectral studies of ribonucleotides, MHHCo, and ribonucleotides-MHCCo adducts, we propose that the nitrogen base, carbonyl and phosphate moiety of ribose nucleotides interact with the outer divalent metal ion of the MHCCo. A higher affinity as well as larger amount of adsorption of all the four ribonucleotides was found on the surface of FeHCCo, having a surface area of $238.67 \mathrm{~m}^{2} / \mathrm{g}$. Based on our finding, it is proposed that surface area of MHCCos plays an important role in ribonucleotides adsorption by MHCCos. Among nucleotides studied adsorption affinity of $5^{\prime}$-AMP was found maximum.
\end{abstract}

\section{Keywords: $\quad$ Adsorption; Isotherms;}

hexacyanocobaltate(III); Ribonucleotides; Surface area

\section{Abbreviations}

IR: Infrared Spectroscopy; FE-SEM: Field Emission Scanning Electron Microscopy; MHCCo: Metal Hexacyanocobaltate; 5'-AMP: Adenosine 5'-Monophosphate; 5'-GMP: Guanosine 5'Monophosphate; 5'-CMP: Cytidine 5'-Monophosphate; 5'-UMP: Uridine 5'-Monophosphate

\section{Introduction}

It is generally accepted that the transition metal ions present in primeval seas, might have complexed with simple molecule available to them. The concentration of these transition metals in primeval seas was estimated to be 7-100 nM [1]. Kobayshi and Ponnamperuma, 1985 [2] also have reviewed the possible roles of trace elements in chemical evolution. Cyanide has been reported as a product in several simulated prebiotic experiments and is supposed to have been readily available under primitive Earth conditions [3,4]. Since cyanide ion is negatively charged, a good sigma donor and a good $\pi$-acceptor [5], a strong ligand, is capable of forming stable complexes with different transition metal ions in different oxidation states [6]. It is therefore, reasonable to assume that cyanide ions might have complexed with different transition metal ions present in primeval seas, forming a number of soluble and insoluble metal cyanide complexes. As most of the double metal cyanide (DMC) complexes are insoluble in water, it is reasonable to assume that they might have locally settled at the bottom of primeval seas or at its shores. Double metal cyanide complexes could have provided surfaces onto which biomonomers concentered by means of selective adsorption. Biomonomers so concentrated could have been protected from degradation and undergone condensation, oligomerization and redox reactions etc. producing the essential molecules for the formation of first living cell.

Double metal cyanide (DMC), $\mathrm{M}_{\mathrm{a}}^{\mathrm{I}}\left[\mathrm{M}^{\mathrm{II}}(\mathrm{CN})_{\mathrm{n}}\right]_{\mathrm{b}} \cdot \mathrm{xH}_{2} \mathrm{O}$ is an inorganic coordinated polymer with three-dimensional network, in which the inner metal $\mathrm{M}^{\mathrm{II}}$ is linked with the external metal $\mathrm{M}^{\mathrm{I}}$ by several cyano-bridges $\left(\mathrm{M}^{\mathrm{II}}-\mathrm{C} \equiv \mathrm{N}-\mathrm{M}^{\mathrm{I}}\right.$, generally $\mathrm{M}^{\mathrm{I}}=$ divalent metal ions such as $\mathrm{Zn}^{2+}, \mathrm{Fe}^{2+}, \mathrm{Cd}^{2+}, \mathrm{Co}^{2+}, \mathrm{Cu}^{2+}, \mathrm{Ni}^{2+}, \mathrm{Mn}^{2+}$ etc. and $\mathrm{M}^{\mathrm{II}}=$ transitional metal ions such as $\mathrm{Fe}^{2+}, \mathrm{Fe}^{3+}, \mathrm{Co}^{2+}, \mathrm{Ni}^{2+}, \mathrm{Cr}^{3+}$, $\mathrm{Mo}^{4+}$ etc.). The external metal $\mathrm{M}^{\mathrm{I}}$ on the surface of the DMC is generally considered to be the active site for their catalytic functions. Aside from their solid state chemistry and structural characteristics, these compounds have gathered intense recent interest because of their molecular magnetism, photo magnetism, ferromagnetism [7-9], optical [10], electrochemical [11], ion-exchange [12] and ion sensing [13] properties. Beside these applications DMC might have acted as prebiotic catalyst during the course of chemical evolution [14-24].

It is well known that ribonucleic acid (RNA) molecule is a polymer of ribonucleotides viz., $5^{\prime}$-AMP, $5^{\prime}$-GMP, $5^{\prime}$-CMP and $5^{\prime}$-UMP, linked through phosphodiester bonds. It is, therefore, a matter of great interest to understand how nucleotide molecules were concentrated from dilute aqueous solutions of primordial soup and subsequently polymerized into ribonucleic acid (RNA) and deoxyribonucleic acid (DNA). Ribonucleic acid can catalyze the formation of peptide bond in the ribosome, a key step in protein synthesis and to storing genetic information, suggests that RNA might have played an extremely important role in the formation of the first living system [25-29]. The mineral surfaces could have played a fundamental role in the configuration and protection of biopolymers on the early Earth. In this connection, the adsorption of RNA components on mineral surfaces has been studied extensively [30-37]. 
In the context of the chemical evolution it seems relevant to study the interaction between RNA components and metal hexacyanocobaltates (MHCCos). The present contribution aims at studying in detail the adsorption of all four nucleotides on the surface of metal hexacyanocobalatates. Thus we have synthesized a series of metal hexacyanocobalatate(III), e.g., Zn-, Ni-, Mn-, FeHCCo and studied the interaction with ribonuclotides namely, 5'-AMP, 5'-GMP, 5'-UMP and 5'-CMP as to find the comparative study with the previously studied DMC-nucleotides interaction.

\section{Materials and Methods}

\section{Chemicals}

Potassium hexacyanocobaltate(III) (Fluka), manganese(II) nitrate (E. Merck), iron(II) nitrate (E. Merck), nickel(II) nitrate (E. Merck), zinc(II) nitrate (E. Merck), 5'-AMP (Sigma-aldrich), 5'-GMP (Sigmaaldrich), 5'-CMP (Sigma-aldrich), 5'-UMP (Sigma-aldrich) were used as received. All other chemicals were of analytical reagent grade. Distilled deionized water (Millipore) was used throughout the studies.

\section{Preparation of Metal Hexacyanocobaltate (III)}

MHCCos were synthesized from potassium hexacyanocobaltate(III), $\mathrm{K}_{3}\left[\mathrm{Co}(\mathrm{CN})_{6}\right]$ following the method of Kaye and Long (2005) [38].A solution of $\mathrm{K}_{3}\left[\mathrm{Co}(\mathrm{CN})_{6}\right](10 \mathrm{mmol})$ in $100 \mathrm{~mL}$ of water was added drop wise to a solution of the respective metal (II) nitrate $(18 \mathrm{mmol})$ in $100 \mathrm{~mL}$ of water with constant stirring. The resulting mixture was kept overnight at room temperature, filtered through a Buchner funnel, washed thoroughly with Millipore water. The precipitate obtained was dried in an air. The dried product was powdered and sieved through 100 mesh size sieve.

\section{X-ray diffraction analysis (XRD)}

The X-ray diffraction analysis of all MHCCoswas carried out using Brucker AXS D8 Advance Diffractometer with $\mathrm{Cu}-\mathrm{ka}$ radiation $(\lambda=0.1542 \mathrm{~nm})$. The relative-intensity data and interplanner spacing (d) were in good agreement with the reported values (JCPDS file no.). The purity of MHCCos was checked by comparing the X-ray diffraction data of the complexes.

\section{CHN and AAS analysis}

The percentage of carbon $(\mathrm{C})$, hydrogen $(\mathrm{H})$ and nitrogen $(\mathrm{N})$ present in MHCCos was recorded on an Elementar Vario ELHI CHNS analyzer while the percentage of transition metal was determined by Atomic Absorption Spectroscopy (Perkin Elmer AAnalyst 800).

\section{Thermogravimetric and differential thermal analysis (TG/ DTA)}

Thermograms for thermogravimetric and differential thermal analysis of all the metal(II) hexacyanocobaltate(III) were recorded on thermal analyzer(EXSTAR TG/DTA 6300, SII Nano Technology Inc. Japan) at a heating rate of $10^{\circ} \mathrm{C} / \mathrm{min}$. All measurements were carried under a dinitrogen atmosphere using $\mathrm{Al}_{2} \mathrm{O}_{3}$ as a reference in the temperature range $25-500{ }^{\circ} \mathrm{C}$.

\section{Field emission scanning electron microscopy (FE-SEM)}

FE-SEM was employed to observe the attachment of ribonucleotides on the surface of MHCCos. FE-SEM (Field Emission Scanning Electron Microscopy) images and EDX (Energy dispersive X-ray analysis) spectra were recorded using a FEI Quanta 200F microscope equipped with an EDX spectrometer operating at $20 \mathrm{kV}$.

\section{Surface area measurement}

The BET (Brunauer, Emmett, and Teller) surface area of the samples was measured by nitrogen adsorption isotherms on Nova 2200e (Quantachrome) instrument. The surface area was determined by physical adsorption of $\mathrm{N}_{2}$ gas at its boiling temperature.The determined values of the surface areas of MHCCos are given in Table 1 .

\begin{tabular}{|l|l|}
\hline MHCCo & Surface area $\left(\mathbf{m}^{2} / \mathbf{g}\right)$ \\
\hline FeHCCo & 238.67 \\
\hline ZnHCCo & 213.64 \\
\hline MnHCCo & 111.85 \\
\hline NiHCCo & 100.19 \\
\hline
\end{tabular}

Table 1: Surface area of MHCCos.

\section{Spectral studies}

The electronic spectra of $5^{\prime}$-AMP, 5 '-GMP, 5'-CMP and 5'-UMP have been recorded on a Shimadzu UV-16001 spectrophotometer at characteristic values of $\lambda_{\max } 259,254,278$ and $262 \mathrm{~nm}$, respectively.

The infrared spectra of adsorbents, adsorbates and adsorption adducts were recorded using $\mathrm{KBr}$ pressed disc technique by a FT-IR spectrophotometer (Perkin Elmer-1600 Series).

\section{Adsorption protocol}

For determining the adsorption isotherms of ribonucleotides on metal(II) hexacyanocobaltate(III) complexes, a moderate concentration range of ribonucleotides

$\left(1.0 \times 10^{-4} \mathrm{M}\right.$ to $\left.3.0 \times 10^{-4} \mathrm{M}\right)$ has been chosen in order to get absorbance of ribonucleotides in the suitable range of the absorbance scale on a UV-spectrophotometer.

Twenty five milligrams of the MHCCo were added to $5.0 \mathrm{~mL}$ of different concentration of aqueous solution of nucleotide $\left(1.0 \times 10^{-4} \mathrm{M}\right.$ to $\left.3.0 \times 10^{-4} \mathrm{M}\right)$. Adsorption of ribonucleotides was studied at physiological $\mathrm{pH}(\sim 7.0)$ on all MHCCos. The desired $\mathrm{pH}$ value of the resultant solution was adjusted by adding either small amount of 0.01 $\mathrm{M} \mathrm{HCl}$ or $0.01 \mathrm{M} \mathrm{NaOH}$ solution. Mixtures were shaken properly for about 2 min on Vortex shaker (Spinix) and kept at room temperature. After $24 \mathrm{~h}$ the reaction mixture was centrifuged at $5,000 \mathrm{rpm}$ on centrifuge machine (REMI R4C) for $30 \mathrm{~min}$. Absorbance of the supernatant liquid was measured at the characteristic $\lambda_{\max }$ of the nucleotides. Concentration of nucleotides after adsorption for $24 \mathrm{~h}$ was measured by comparing optical density (O.D.) of the nucleotides with the help of calibration curve. The amount of nucleotide adsorbed was calculated with the absorbance of nucleotide before and after adsorption. The nucleotide-MHCCo adduct was washed thoroughly with Millipore water, dried and subjected to IR and SEM studies. 
Citation: Rachana S, Anand Kumar, Asif Iqubal Md, Kamaluddin (2015) Role of Double Metal Cyanides in Chemical Evolution: Interaction of Ribose Nucelotides with Metal Hexacyanocobaltate(III). Astrobiol Outreach 3: 138. doi:10.4172/2332-2519.1000138

Page 3 of 9

\section{Statistical analysis}

Adsorption studies were conducted in triplicate. The result of percent binding was expressed as mean \pm standard deviations.

\section{Results and Discussion}

The XRD patterns of MnHCCo, FeHCCo, NiHCCo and ZnHCCo were analyzed using JCPDS (Joint Committee on Powder Diffraction Standards) diffraction files and are shown in Figure 1. The JCPDS data of MHCCos were carefully compared. All the diffraction peaks of the experimental pattern matched with those of the relative intensities of the compounds MnHCCo (JCPDS file number 22-1167), FeHCCo (JCPDS file number 89-3736), NiHCCo (JCPDS file number 22-1184) and ZnHCCo (JCPDS file number 32-1468). The MHCCos were also characterized by TGA/DT analysis. The thermograms obtained are shown in Figure 2. The thermograms of MHCCos showed a mass loss corresponding to nearly $14,15,15$, and 14 water molecules, for MnHCCo, FeHCCo, NiHCCo, and ZnHCCo, respectively. The elemental analysis data is given in a supplementary section (Table S1). Results of elemental analysis affirm that experimental values are in good agreement with theoretical values. From the XRD, AAS, CHN, TGA/DT analyses, the closest molecular formulae of the synthesized MHCCo complexes are as follows.

$$
\begin{aligned}
& \mathrm{Mn}_{3}\left[\mathrm{Co}(\mathrm{CN})_{6}\right]_{2} \cdot 14 \mathrm{H}_{2} \mathrm{O} \\
& \mathrm{Fe}_{3}\left[\mathrm{Co}(\mathrm{CN})_{6}\right]_{2} \cdot 15 \mathrm{H}_{2} \mathrm{O} \\
& \mathrm{Ni}_{3}\left[\mathrm{Co}(\mathrm{CN})_{6}\right]_{2} \cdot 15 \mathrm{H}_{2} \mathrm{O} \\
& \mathrm{Zn}_{3}\left[\mathrm{Co}(\mathrm{CN})_{6}\right]_{2} \cdot 14 \mathrm{H}_{2} \mathrm{O}
\end{aligned}
$$

\begin{tabular}{|l|l|l|l|l|}
\hline MHCCos & $\mathbf{H}(\%)$ & $\mathbf{C}(\%)$ & $\mathbf{N}(\%)$ & $\mathbf{C o}(\%)$ \\
\hline $\mathrm{Mn}_{3}\left[\mathrm{Co}(\mathrm{CN})_{6}\right]_{2} \cdot 14 \mathrm{H}_{2} \mathrm{O}$ & $3.03(3.30) \mathrm{a}$ & $16.51(17.00)$ & $18.61(19.83)$ & $13.66(13.93)$ \\
\hline $\mathrm{Fe}_{3}\left[\mathrm{Co}(\mathrm{CN})_{6}\right]_{2} \cdot 15 \mathrm{H}_{2} \mathrm{O}$ & $3.12(3.45)$ & $16.28(16.58)$ & $19.02(19.35)$ & $13.17(13.59)$ \\
\hline $\mathrm{Ni}_{3}\left[\mathrm{Co}(\mathrm{CN})_{6}\right]_{2} \cdot 15 \mathrm{H}_{2} \mathrm{O}$ & $3.11(3.42)$ & $15.99(16.43)$ & $18.98(19.17)$ & $13.03(13.47)$ \\
\hline $\mathrm{Zn}_{3}\left[\mathrm{Co}(\mathrm{CN})_{6}\right]_{2} \cdot 14 \mathrm{H}_{2} \mathrm{O}$ & $2.98(3.18)$ & $16.07(16.40)$ & $12.94(19.13)$ & $13.02(13.43)$ \\
\hline
\end{tabular}

Table S1: Elemental analysis of MHCCos. ${ }^{*}$ Bracket values are theoretical ones.

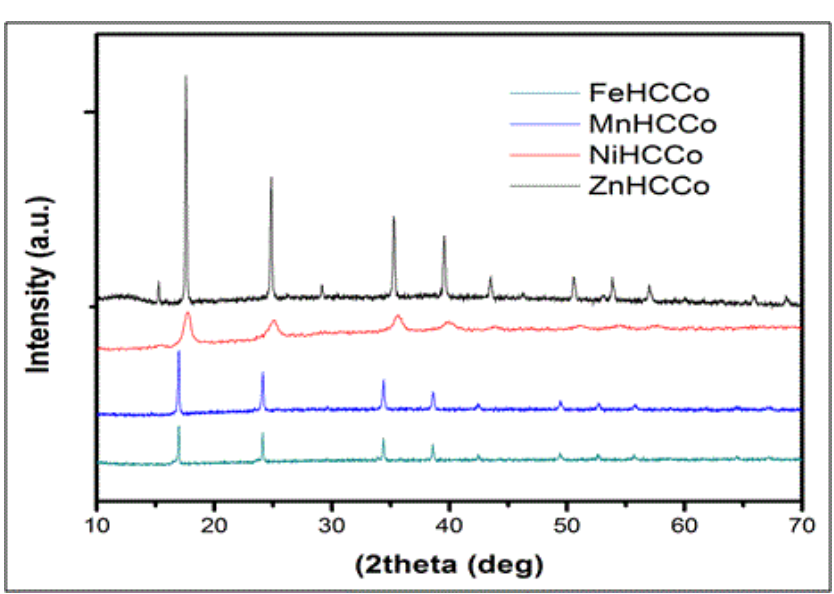

Figure 1: XRD spectra of metal hexacyanocobaltates (MHCCos).

The primary objective of this work was to check the suitability of MHCCos as an adsorbent for the interaction with ribose nucleotides. The preliminary studies on interaction of $5^{\prime}$-AMP, $5^{\prime}$-GMP, $5^{\prime}$-CMP and 5'-UMP with MHCCos were carried out at neutral $\mathrm{pH}(\sim 7.0)$. Interaction of ribonucleotides can be correlated with negative charge on the phosphate group and positively charged surface of MHCCos. The $\mathrm{pK}_{\mathrm{a} 2}$ values for $5^{\prime}$-AMP, 5'-GMP, 5'-CMP and 5'-UMP are 6.1, 6.1, 6.3 and 6.3, respectively [39]. In acidic medium nucleotides get protonated, and thus have some more positive charge. Hence at lower $\mathrm{pH}$, interaction between positively charged surface of MHCCo and nucleotide is likely not significant. At higher $\mathrm{pH}$ adsorption is less which may be due to the competitive interaction of available- $\mathrm{OH}$ with MHCCo(III).

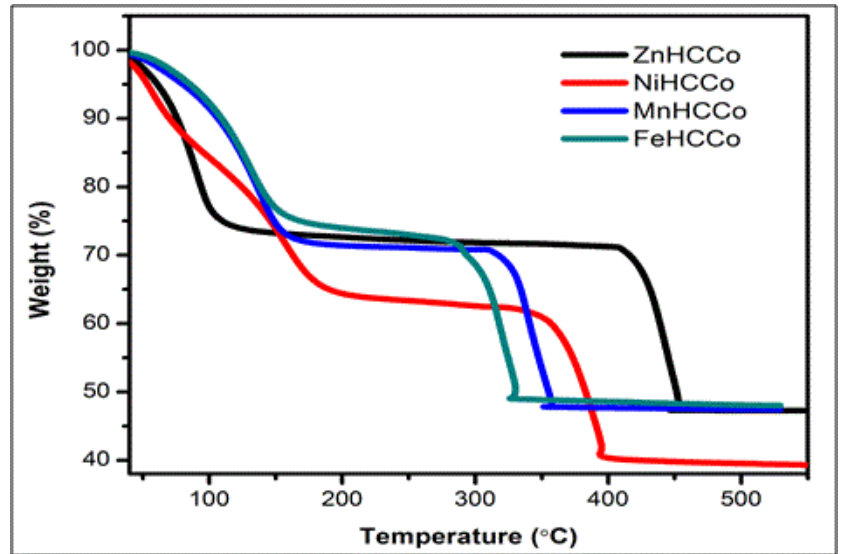

Figure 2: Thermograms of MHCCos.

Dianion nucleotide will form by the dissociation of second proton of the phosphate group in the nucleotide.This implies that at neutral $\mathrm{pH}$ all the four nucleotides will exist in their dianionic form and thus at $\mathrm{pH}$ above $\mathrm{pK}_{\mathrm{a} 2}$, nucleotides should show higher interaction between negatively charged nucleotide and the positively charged surface of MHCCos. It has also been reported that dianionic nucleotides form stronger complexes with transition metal cations than monoionic nucleotides [40]. Other workers also support that at neutral $\mathrm{pH}$ adsorption of ribonucleotides was maximum on DMC [15,16,21,22]; metal oxides [41-43] and clays [44,45,31]. Therefore, subsequent adsorption studies were carried out at neutral $\mathrm{pH}(\sim 7.0)$ over a wide concentration range of ribonucleotides $\left(1.0 \times 10^{-4} \mathrm{M}\right.$ to $\left.3.0 \times 10^{-4} \mathrm{M}\right)$ and were found to follow Langmuir Adsorption Isotherms. Adsorption 
Citation: Rachana S, Anand Kumar, Asif Iqubal Md, Kamaluddin (2015) Role of Double Metal Cyanides in Chemical Evolution: Interaction of Ribose Nucelotides with Metal Hexacyanocobaltate(III). Astrobiol Outreach 3: 138. doi:10.4172/2332-2519.1000138

Page 4 of 9

isotherms were obtained by plotting the amount of nucleotide adsorbed, $\mathrm{X}_{\mathrm{e}}(\mathrm{mg} / \mathrm{g})$, versus their equilibrium concentration Ce (mol $\mathrm{L}^{-1}$ ). The adsorption isotherms of ribose nucleotides for FeHCCo, ZnHCCo,MnHCCo, and NiHCCo are shown in Figure 3. The initial portion of the isotherm represents a linear relationship between the amounts adsorbed and the equilibrium concentration of the ribose nucleotides. At a higher concentration range, the isotherms showed a saturation phenomenon indicating no further adsorption. From the data of the curve at saturation, the percent binding was calculated and is listed in Table 2.

\begin{tabular}{|l|l|l|l|l|}
\hline Ribose Nucleotides & FeHCCo & ZnHCCo & MnHCCo \\
\hline 5'-AMP & $84.36 \pm 1.36$ & $62.22 \pm 4.80$ & $52.14 \pm 0.59$ \\
\hline $\mathbf{5}$-GMP & $79.79 \pm 1.67$ & $64.16 \pm 2.03$ & $49.10 \pm 2.64$ & $39.41 \pm 4.19$ \\
\hline $\mathbf{5}$ '-CMP & $58.00 \pm 0.90$ & $38.47 \pm 0.93$ & $32.93 \pm 0.90$ & $30.43 \pm 2.39$ \\
\hline $5^{\prime}-$ UMP & $43.18 \pm 1.48$ & $34.65 \pm 1.31$ & $26.93 \pm 0.90$ \\
\hline
\end{tabular}

Table 2: Percent binding ${ }^{\star}$ of ribonucleotides on MHCCo at neutral Ph.

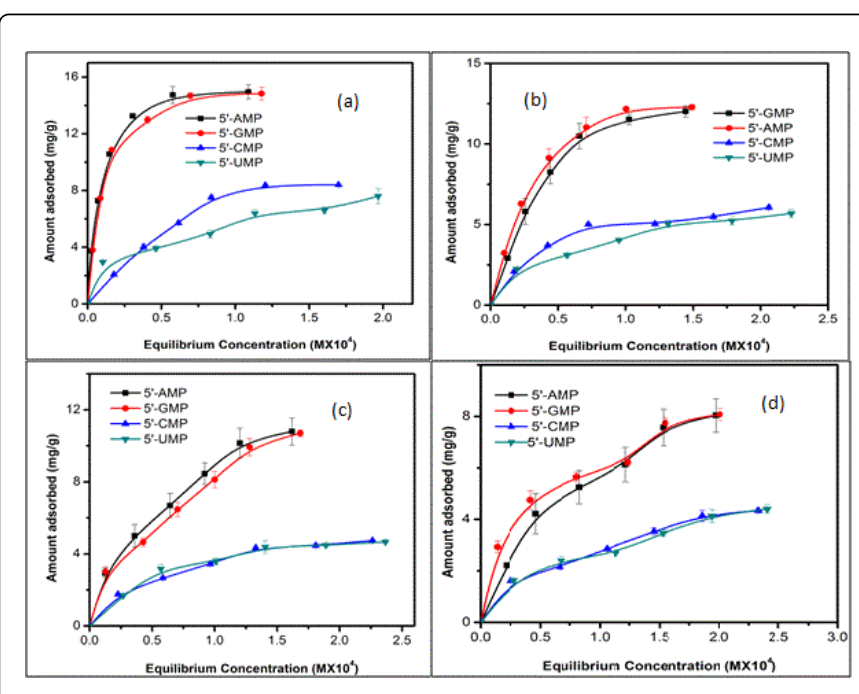

Figure 3: Adsorption isotherms of Ribose Nucleotides on (a) FeHCCo, (b) ZnHCCo, (c) MnHCCo and (d) NiHCCo at pH=7.0.

The adsorption data were fitted in Langmuir adsorption isotherm as given below.
$C_{e} / X_{e}={ }^{C} e / X_{m}+1 / X_{m} k_{L}$

Where,

$\mathrm{C}_{\mathrm{e}}=$ equilibrium concentration of nucleotide (mole/liter)

$\mathrm{X}_{\mathrm{e}}=$ amount $(\mathrm{mg})$ of nucleotides adsorbed per gram weight of adsorbent

$\mathrm{X}_{\mathrm{m}}=$ amount of nucleotides adsorbed at saturation $(\mathrm{mg} / \mathrm{g})$

$\mathrm{K}_{\mathrm{L}}=$ Langmuir adsorption constant $(\mathrm{L} / \mathrm{mol})$

A typical plot of $\mathrm{C}_{e} / \mathrm{X}_{\mathrm{e}} \mathrm{V}_{s} \mathrm{C}_{\mathrm{e}}$ in case of FeHCCo is a straight line (Figure 4) and is found to follow Langmuir adsorption isotherm. Similar plots were also obtained in case of MnHCCo, ZnHCCo and $\mathrm{NiHCC}$. The plots are given in supplementary section (Figure S1). The linear nature of the Langmuir plots confirms the formation of a monolayer of the ribonucleotides on MHCCos. $\mathrm{K}_{\mathrm{L}}$ and $\mathrm{X}_{\mathrm{m}}$ values were determined and are shown in Table 3 . Higher $\mathrm{X}_{\mathrm{m}}$ values indicate a higher amount of nucleotide adsorbed on MHCCos for monolayer formation, while $\mathrm{K}_{\mathrm{L}}$ value is related to the enthalpy of adsorption. Both the parameters $\mathrm{X}_{\mathrm{m}}$ and $\mathrm{K}_{\mathrm{L}}$ depend on the nature of the adsorbate and the adsorbent. If the amount of nucleotide adsorbed on MHCCos is higher (high $\mathrm{X}_{\mathrm{m}}$ ), it is not necessary that they will bind very tightly on the adsorbent and hence a linear dependency of $\mathrm{X}_{\mathrm{m}}$ on $\mathrm{K}_{\mathrm{L}}$ is not always true.

\begin{tabular}{|c|c|c|c|c|c|c|c|c|c|c|c|c|}
\hline \multirow[t]{2}{*}{ MHCCo } & \multicolumn{3}{|c|}{ 5'-AMP } & \multicolumn{3}{|c|}{5 '-GMP } & \multicolumn{3}{|c|}{5 '-СMP } & \multicolumn{3}{|c|}{5 '-UMP } \\
\hline & $\mathbf{R}^{2}$ & $\begin{array}{l}X_{m} \\
(\mathrm{mg} / \mathrm{g})\end{array}$ & $\begin{array}{l}\mathrm{KL} \times 10^{4} \\
(\mathrm{~L} / \mathrm{mol})\end{array}$ & $\mathbf{R}^{2}$ & $\begin{array}{l}X_{m} \\
(\mathrm{mg} / \mathrm{g})\end{array}$ & $\begin{array}{l}\mathrm{KL} \times 10^{4} \\
(\mathrm{~L} / \mathrm{mol})\end{array}$ & $\mathbf{R}^{2}$ & $\begin{array}{l}X_{m} \\
(m g / g)\end{array}$ & $\begin{array}{l}\mathrm{KL} \times 10^{4} \\
(\mathrm{~L} / \mathrm{mol})\end{array}$ & $\mathbf{R}^{2}$ & $\begin{array}{l}X_{m} \\
(\mathrm{mg} / \mathrm{g})\end{array}$ & $\begin{array}{l}\mathrm{KL} \times 10^{4} \\
(\mathrm{~L} / \mathrm{mol})\end{array}$ \\
\hline FeHCCo & 0.99 & 16.13 & 2.13 & 0.99 & 16.39 & 2.09 & 0.92 & 13.52 & 2.93 & 0.90 & 8.77 & 1.64 \\
\hline ZnHCCo & 0.94 & 14.92 & 1.83 & 0.97 & 15.38 & 2.15 & 0.98 & 7.04 & 1.47 & 0.96 & 7.09 & 1.55 \\
\hline MnHCCo & 0.86 & 14.28 & 2.57 & 0.88 & 15.38 & 2.67 & 0.98 & 6.21 & 1.63 & 0.99 & 6.25 & 1.43 \\
\hline NiHCCo & 0.99 & 11.76 & 2.46 & 0.95 & 9.52 & 1.60 & 0.92 & 6.03 & 1.90 & 0.90 & 5.75 & 1.71 \\
\hline
\end{tabular}

Table 3: Langmuir constants for adsorption of ribose nucleotides on MHCCo complexes. 
Citation: Rachana S, Anand Kumar, Asif Iqubal Md, Kamaluddin (2015) Role of Double Metal Cyanides in Chemical Evolution: Interaction of Ribose Nucelotides with Metal Hexacyanocobaltate(III). Astrobiol Outreach 3: 138. doi:10.4172/2332-2519.1000138

Page 5 of 9

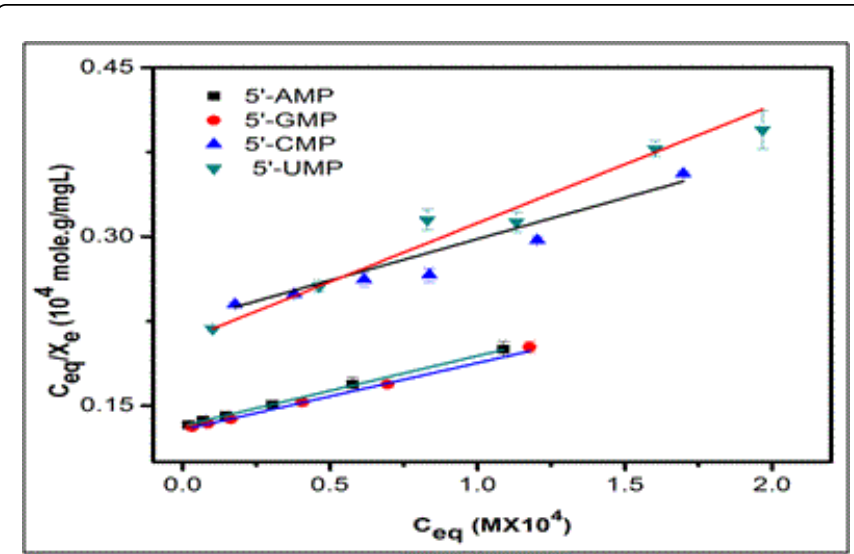

Figure 4: A typical Langmuir adsorption isotherm of ribonucleotides on FeHCCo.
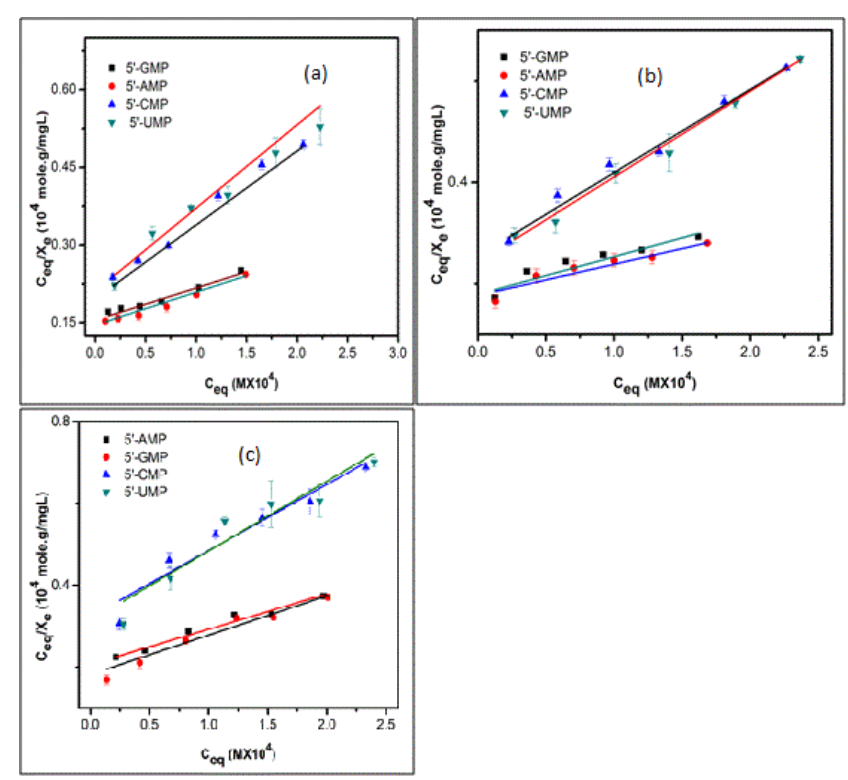

Figure S1: Langmuir plots of ribonucleotides on (a) ZnHCCo, (b) MnHCCo and (c) NiHCCo; Each point is the mean \pm S.D, $n=3$.
FT-IR spectroscopy was employed to investigate the interaction between the RNA components (5'-AMP, 5'-GMP, 5'-CMP, 5'-UMP) and MHCCos. A typical FT-IR spectra of 5 '-GMP, FeHCCo and 5'GMP-FeHCCo adduct at neutral $\mathrm{pH}$ were illustrated in Figure 5. The main peaks of the FeHCCo were as the following: broad peak at 1608 $\mathrm{cm}^{-1}$ corresponded to the $\mathrm{O}-\mathrm{H}$ bending of interstitial water molecule and peak at $455 \mathrm{~cm}^{-1}$ was attributed with the $\mathrm{Co}-\mathrm{CN}$ bending. For the $5^{\prime}$-GMP molecule, the peaks at $1640 \mathrm{~cm}^{-1}$ and $1680 \mathrm{~cm}^{-1}$ were assigned to $\mathrm{N}-\mathrm{H}$ bending and $>\mathrm{C}=\mathrm{O}$ stretching mode, respectively. The peak centered at $1080 \mathrm{~cm}^{-1}$ and $978 \mathrm{~cm}^{-1}$ were assigned to the $v\left(\mathrm{PO}_{3}{ }^{2-}\right)$ antisymmetric and $v\left(\mathrm{PO}_{3}{ }^{2-}\right)$ symmetric vibration, respectively. A significant change of characteristics frequencies in 5 '-GMP-FeHCCo adduct indicates an interaction between the 5 '-GMP and FeHCCo. A shift towards lower frequency of $>\mathrm{C}=\mathrm{O}$ stretching from 1680 to 1670 shows the involvement of the $>\mathrm{C}=\mathrm{O}$ group in the interaction of $5^{\prime}$ GMP with FeHCCo. The strong peaks of $v\left(\mathrm{PO}_{3}{ }^{2-}\right)$ antisymmetric $(1080$ $\left.\mathrm{cm}^{-1}\right)$ and $v\left(\mathrm{PO}_{3}{ }^{2-}\right)$ symmetric $\left(978 \mathrm{~cm}^{-1}\right)$ shifted to the frequency $1110 \mathrm{~cm}^{-1}$ and $1014 \mathrm{~cm}^{-1}$, indicating that interaction is taking place through the phosphate moiety of $5^{\prime}$-GMP with FeHCCo. The absorption bands at $1490 \mathrm{~cm}$-1 of 5'-GMPdue to N7-C8 stretching mode of the imidazole ring shifted to $1485 \mathrm{~cm}^{-1}$ was suggested that lone pair electron of $\mathrm{N}-7$ position also involve in electrostatic bonding of purine nucleotides with FeHCCo. Small shifting of pyrimidine and imidazole ring frequencies in ribonucleotide was also observed upon interaction with FeHCCo. Beside 5'-GMP considerable shifting in vibrational frequencies of other nucleotides ( $5^{\prime}$-AMP, $5^{\prime}$-CMP and $5^{\prime}$ UMP) was observed upon interaction with FeHCCo (Table 4). The FTIR spectra of the other ribonucleotides (5'-AMP, 5'-CMP and $5^{\prime}$ UMP) upon adsorption onto FeHCCo were given in the supplementary section (Figure S2). Similar changes in frequencies of all ribonucleotides with other MHCCos are summarized in Table S2S4. Therefore significant shift in typical infrared frequency of $>C=O$, amino and phosphate groups suggested that the adsorption of ribonucleotides is a surface phenomenon occurring on the surface of MHCCos. Typical infrared frequencies of MHCCos were found to be almost unaltered suggesting that ribonucleotide molecules do not enter into the coordination sphere of MHCCos by replacing $\mathrm{CN}$-ions. Further, insertion of ribonucleotides in the coordination sphere of MHCCos is very unlikely as $\mathrm{CN}$-being a strong field ligand and can only be substituted by other ligands under the presence of UV illumination [46]. On the basis of above results we infer that the interaction of ribose nucleotides occurs through the outer metal ion of the MHCCos.

\begin{tabular}{|c|c|c|c|c|c|c|c|c|}
\hline Group/Moiety & 5'-AMP & $\begin{array}{l}\text { Adsorbed 5'- } \\
\text { AMP }\end{array}$ & 5'-GMP & $\begin{array}{l}\text { Adsorbed 5'- } \\
\text { GMP }\end{array}$ & 5'-UMP & $\begin{array}{l}\text { Adsorbed 5'- } \\
\text { UMP }\end{array}$ & 5'-СMP & $\begin{array}{l}\text { Adsorbed 5'- } \\
\text { CMP }\end{array}$ \\
\hline $\mathbf{N H}_{2}$ & 1645 & 1689 & 1640 & 1639 & - & - & 1688 & 1681 \\
\hline$C(6)=0$ & - & - & 1680 & 1670 & - & - & - & - \\
\hline$C(2)=0$ & - & - & - & - & 1681 & 1667 & 1716 & 1722 \\
\hline $\begin{array}{l}\text { Pyrimidine/ } \\
\text { Imidazole vibration }\end{array}$ & 1330 & 1333 & 1536 & 1538 & - & - & - & - \\
\hline Imidazole & 1215 & 1219 & 1368 & 1361 & - & - & - & - \\
\hline UN-7-C-8 + ठC-8-H & 1480 & 1485 & 1490 & 1485 & - & - & - & - \\
\hline
\end{tabular}


Citation: Rachana S, Anand Kumar, Asif Iqubal Md, Kamaluddin (2015) Role of Double Metal Cyanides in Chemical Evolution: Interaction of Ribose Nucelotides with Metal Hexacyanocobaltate(III). Astrobiol Outreach 3: 138. doi:10.4172/2332-2519.1000138

Page 6 of 9

\begin{tabular}{|c|c|c|c|c|c|c|c|c|}
\hline $\begin{array}{l}\mathrm{PO}_{3}{ }^{2-} \\
\text { stretching }\end{array}$ antisymmetric & 1032 & 1110 & 1080 & 1110 & 1080 & 1103 & 1088 & 1111 \\
\hline $\begin{array}{ll}\mathrm{PO}_{3}{ }^{2}- & \text { symmetric } \\
\text { stretching }\end{array}$ & 979 & 1012 & 978 & 1014 & 980 & 1019 & 985 & 1017 \\
\hline
\end{tabular}

Table 4: Typical infrared spectral frequencies $\left(\mathrm{cm}^{-1}\right)$ of ribonucleotides before and after absorption on FeHCCo.

\begin{tabular}{|c|c|c|c|c|c|c|c|c|}
\hline Group/Moiety & 5'-AMP & $\begin{array}{l}\text { Adsorbed 5'- } \\
\text { AMP }\end{array}$ & 5'-GMP & $\begin{array}{l}\text { Adsorbed 5'- } \\
\text { GMP }\end{array}$ & 5'-UMP & $\begin{array}{l}\text { Adsorbed 5'- } \\
\text { UMP }\end{array}$ & 5'-CMP & $\begin{array}{l}\text { Adsorbed } \\
\text { CMP }\end{array}$ \\
\hline $\mathrm{NH}_{2}$ & 1645 & 1660 & 1640 & 1638 & - & - & 1688 & - \\
\hline$C(6)=0$ & - & - & 1680 & 1690 & - & - & - & - \\
\hline$C(2)=0$ & - & - & - & - & 1681 & 1656 & 1716 & 1653 \\
\hline $\begin{array}{l}\text { Pyrimidine/ } \\
\text { Imidazole vibration }\end{array}$ & 1330 & 1342 & 1536 & 1542 & - & - & - & - \\
\hline Imidazole & 1215 & 1218 & 1368 & 1362 & - & - & - & - \\
\hline uN-7-C-8 + סC-8-H & 1480 & 1484 & 1490 & 1497 & - & - & - & - \\
\hline $\begin{array}{l}\mathrm{PO}_{3}{ }^{2} \text {-antisymmetric } \\
\text { stretching }\end{array}$ & 1032 & 1083 & 1080 & 1114 & 1080 & 1117 & 1088 & 1113 \\
\hline $\begin{array}{ll}\mathrm{PO}_{3}{ }^{2}- & \text { symmetric } \\
\text { stretching } & \end{array}$ & 979 & 1018 & 978 & 1000 & 980 & 1003 & 985 & 1006 \\
\hline
\end{tabular}

Table S2: Typical infrared spectral frequencies $\left(\mathrm{cm}^{-1}\right)$ of ribonucleotides before and after absorption on ZnHCCo.

\begin{tabular}{|c|c|c|c|c|c|c|c|c|}
\hline Group/Moiety & 5'-AMP & $\begin{array}{l}\text { Adsorbed 5'- } \\
\text { AMP }\end{array}$ & 5'-GMP & $\begin{array}{l}\text { Adsorbed 5'- } \\
\text { GMP }\end{array}$ & 5'-UMP & $\begin{array}{l}\text { Adsorbed 5'- } \\
\text { UMP }\end{array}$ & 5'-CMP & $\begin{array}{l}\text { Adsorbed 5'- } \\
\text { CMP }\end{array}$ \\
\hline $\mathrm{NH}_{2}$ & 1645 & 1652 & 1640 & 1634 & - & - & 1688 & - \\
\hline$C(6)=0$ & - & - & 1680 & 1690 & - & - & - & - \\
\hline$C(2)=0$ & - & - & - & - & 1681 & 1664 & 1716 & 1657 \\
\hline $\begin{array}{l}\text { Pyrimidine/ } \\
\text { Imidazole vibration }\end{array}$ & 1330 & 1337 & 1536 & 1540 & - & - & - & - \\
\hline Imidazole & 1215 & 1217 & 1368 & 1372 & - & - & - & - \\
\hline uN-7-C-8 + סC-8-H & 1480 & 1483 & 1490 & 1484 & - & - & - & - \\
\hline $\begin{array}{l}\mathrm{PO}_{3}{ }^{2} \text {-antisymmetric } \\
\text { stretching }\end{array}$ & 1032 & 1110 & 1080 & 1100 & 1080 & 1112 & 1088 & 1110 \\
\hline $\begin{array}{l}\mathrm{PO}_{3}{ }^{2}- \\
\text { stretching }\end{array}$ & 979 & 1048 & 978 & 988 & 980 & 985 & 985 & 924 \\
\hline
\end{tabular}

Table S3:Typical infrared spectral frequencies $\left(\mathrm{cm}^{-1}\right)$ of ribonucleotides before and after absorption on MnHCCo.

\begin{tabular}{|c|c|c|c|c|c|c|c|c|}
\hline Group/Moiety & 5'-AMP & $\begin{array}{l}\text { Adsorbed 5'- } \\
\text { AMP }\end{array}$ & 5'-GMP & $\begin{array}{l}\text { Adsorbed 5'- } \\
\text { GMP }\end{array}$ & 5'-UMP & $\begin{array}{l}\text { Adsorbed 5'- } \\
\text { UMP }\end{array}$ & 5'-CMP & $\begin{array}{l}\text { Adsorbed } \\
\text { CMP }\end{array}$ \\
\hline $\mathrm{NH}_{2}$ & 1645 & 1651 & 1640 & 1636 & - & - & 1688 & - \\
\hline$C(6)=0$ & - & - & 1680 & - & - & - & - & - \\
\hline$C(2)=0$ & - & - & - & - & 1681 & 1667 & 1716 & 1653 \\
\hline Pyrimidine/ & 1330 & - & 1536 & 1541 & - & - & - & - \\
\hline
\end{tabular}


Citation: Rachana S, Anand Kumar, Asif Iqubal Md, Kamaluddin (2015) Role of Double Metal Cyanides in Chemical Evolution: Interaction of Ribose Nucelotides with Metal Hexacyanocobaltate(III). Astrobiol Outreach 3: 138. doi:10.4172/2332-2519.1000138

Page 7 of 9

\begin{tabular}{|l|l|l|l|l|l|l|l|l|}
\hline Imidazole vibration & & & & & & & \\
\hline Imidazole & 1215 & - & 1368 & 1361 & - & - & - & - \\
\hline UN-7-C-8 + $\mathbf{~ C - 8 - H ~}$ & 1480 & 1486 & 1490 & - & - & - & - & - \\
\hline $\begin{array}{l}\mathbf{P O}_{3}{ }^{2} \text {-antisymmetric } \\
\text { stretching }\end{array}$ & 1032 & 1110 & 1080 & 1111 & 1080 & 1110 & 1088 & 1109 \\
\hline $\mathbf{P O}_{3}{ }^{2}$-symmetric stretching & 979 & 1086 & 978 & 1086 & 980 & 982 & 985 & 942 \\
\hline
\end{tabular}

Table S4: Typical infrared spectral frequencies $\left(\mathrm{cm}^{-1}\right)$ of ribonucleotides before and after absorption on NiHCCo.

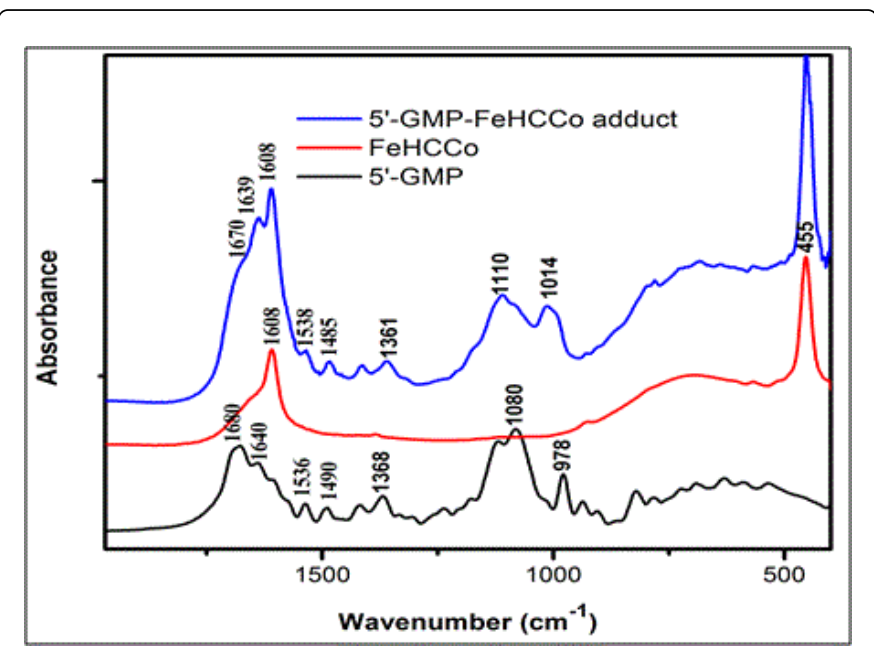

Figure 5: FT-IR spectra of 5'-GMP, FeHCCo and 5'-GMP- FeHCCo adduct.
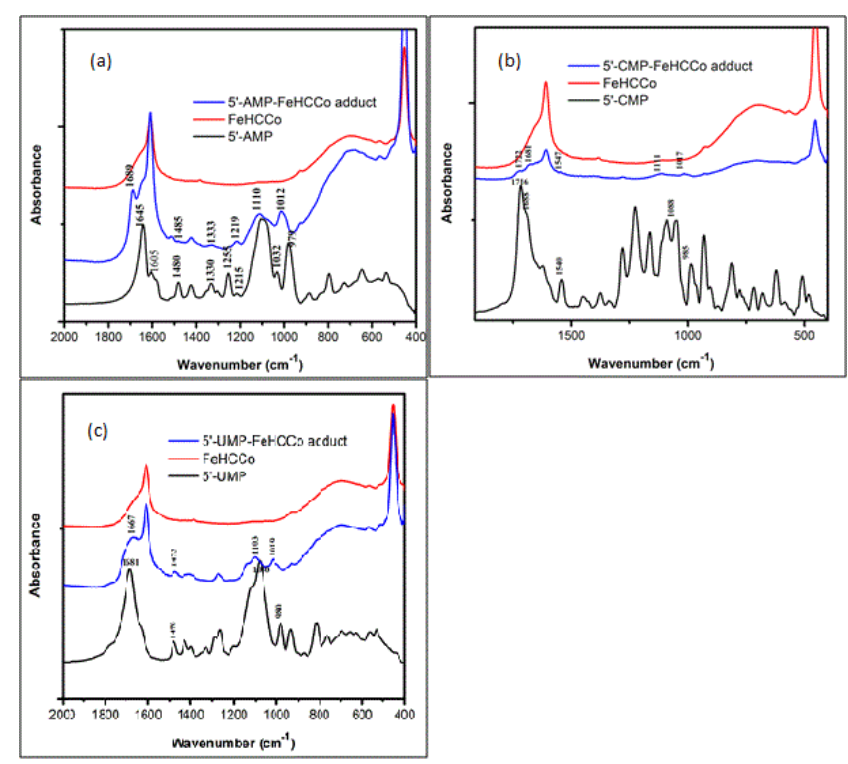

Figure S2: FT-IR spectra of (a) 5'-AMP, (b) 5'-CMP and 5'UMPbefore and after adsorption on FeHCCo.
The tentative structure was proposed for GMP-MHCCo adduct and is shown in Figure 6 where structure of $\left[\mathrm{Co}(\mathrm{CN})_{6}\right]^{3-}$ contains one Co site and four $\mathrm{M}$ sites ( $\mathrm{M}$ being outer metal of MHCCo). Most metal hexacaynometallates have a cubic structure. Metal ions are situated at the corners of the cube and they are octahedrally arranged and coordinated by the nitrogen or carbon end of the cyanide group. This octahedral $\left[\mathrm{Co}^{\mathrm{III}}(\mathrm{CN})_{6}\right]^{3-}$ complex bridged into simple cubic lattice by $\mathrm{M}^{2+}$ ions creates a crystal consisting of alternating $\mathrm{M}^{2+}$ and $\mathrm{Co}^{3+}$ ions connected through cyanide ligand. The charge imbalance between $\left[\mathrm{Co}^{\mathrm{III}}(\mathrm{CN})_{6}\right]^{3-}$ complex and $\mathrm{M}^{2+}$ ion leads to vacancies at one-third of the $\left[\mathrm{Co}^{\mathrm{III}}(\mathrm{CN})_{6}\right]^{3-}$ sites. These vacancies are completed by coordination of water molecules with $\mathrm{M}^{2+}$ metal centers $[47,48]$. The structure shows that the $\mathrm{M}$ (II) binds with the phosphate group and the $>\mathrm{C}=$ Ogroup of GMP, therefore changes occur in the wavelength of $>\mathrm{C}=$ Ostretching and symmetric and antisymmetric vibrations of phosphate group.

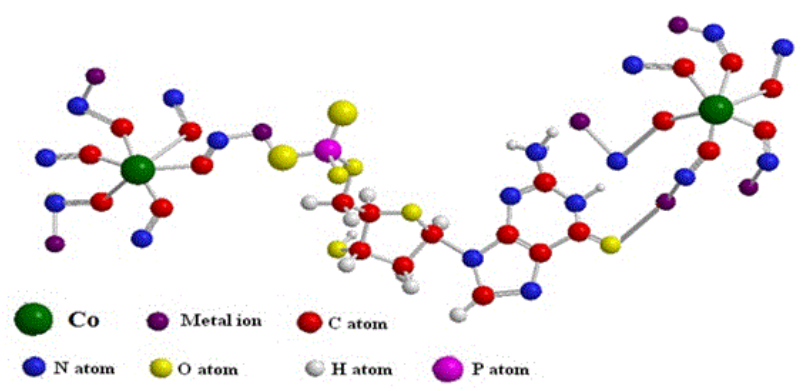

Figure 6: Possible structure of 5'-GMP-MHCCo adduct.

The surface morphology of FeHCCo before and after adsorption of ribonucleotides was investigated using FE-SEM. Representative FeSEM images (Figures $7 \mathrm{a}$ and $7 \mathrm{~b}$ ) show the morphology of FeHCCo before and after adsorption of 5 '-GMP. The FE-SEM images also demonstrated that the surface morphologies of both $7 \mathrm{a}$ and $7 \mathrm{~b}$ are different. Morphologically FeHCCo before adsorption seems to be globular shaped particles of varied size distribution, which aggregated after adsorption. Moreover, the adsorption of $5{ }^{\prime}$-GMP on FeHCCo is further confirmed by the additional peaks for phosphorus in the EDXA spectra (Figure $7 a^{\prime}$ and $7 b^{\prime}$ ). 
Citation: Rachana S, Anand Kumar, Asif Iqubal Md, Kamaluddin (2015) Role of Double Metal Cyanides in Chemical Evolution: Interaction of Ribose Nucelotides with Metal Hexacyanocobaltate(III). Astrobiol Outreach 3: 138. doi:10.4172/2332-2519.1000138

Page 8 of 9

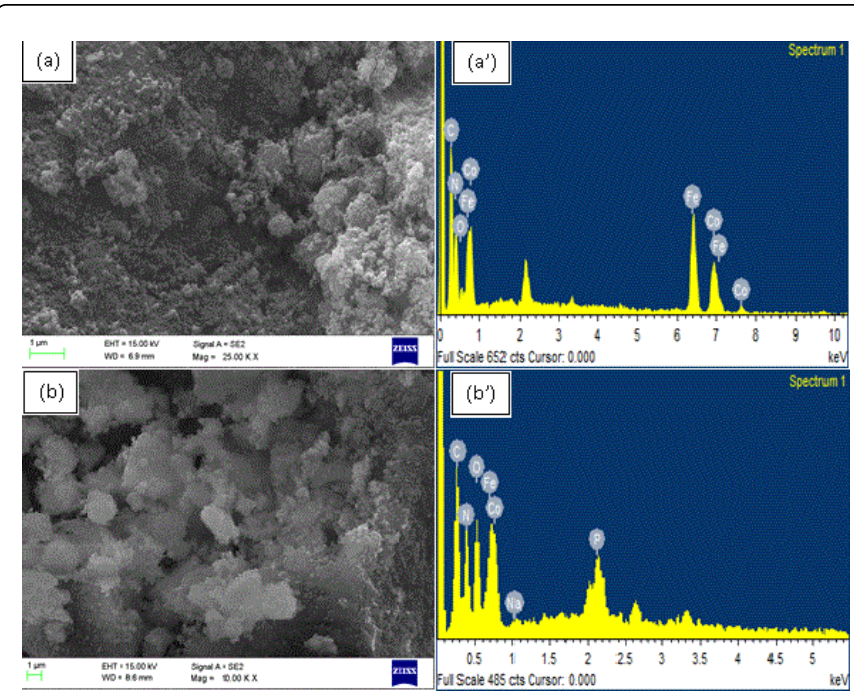

Figure 7: FE-SEM images and EDX spectra of FeHCCo before (a and $\left.a^{\prime}\right)$ and after $\left(b\right.$ and $\left.b^{\prime}\right)$ adsorption of $5^{\prime}$-GMP.

The trend in adsorption (\% binding) of $5^{\prime}$-ribonucleotides for the all MHCCos was found to increase in order:

$$
5^{\prime} \text {-AMP } \sim 5^{\prime} \text {-GMP }>5^{\prime} \text { - CMP }>5^{\prime} \text {-UMP. }
$$

Table 2, shows that percent binding data of purine nucleotides ( 5 'AMP, $5^{\prime}$-GMP) is more compared to that of pyrimidine nucleotides (5'-CMP, 5'-UMP) on MHCCo. These observations may be explained considering structural differences of purine and pyrimidine nucleotides. Purine nucleotides which have one more ring compared to pyrimidine nucleotides and a lone pair of electrons at the N-7 position are adsorbed more strongly on MHCCos than that of pyrimidine nucleotides. In addition absorption affinity of ribonucleotides on MHCCos may also be described in term of differences in molecular weight (size) of the adsorbates. Adsorption would also increase with molecular weight since the larger the solute the greater would be contribution of Van der Waal forces to adsorption affinity.

In the present study adsorption of ribonucleotides on FeHCCo (surface area, $\mathrm{S} . \mathrm{A}=238.67 \mathrm{~m}^{2} / \mathrm{g}$ ) exhibited highest adsorption capacity whereas NiHCCo (S.A. $=100.19 \mathrm{~m}^{2} / \mathrm{g}$ ) showed minimum adsorption. The results of adsorption studies suggest that surface area of the MHCCos plays a dominating role in adsorption process which is consistent with our previous studies. Earlier reports on the interaction of metal hexacyanoferrates [15,21], hexacyanochromates [22] and octacyanomolybdates [24] with ribose nucleotides also showed the maximum adsorption on adouble metal cyanide compound having highest surface area in the series.

\section{Conclusion}

Studies on interaction of ribose nucleotides with metal(II) hexacyanocobaltate(III), (MHCCo), showed that among MHCCos, FeHCCo exhibits the highest adsorption capacity and NiHCCo the lowest for the all ribonucleotides. Adsorption affinity of MHCCo with purine ( $5^{\prime}$-GMP and $5^{\prime}$-AMP) was higher as compared to pyrimidines (5'-CMP and 5'-UMP). The strength of the binding of purine nucleotides is greater than that of the corresponding pyrimidine derivative, an effect owing to the larger size of the planar purine ring. It may be proposed that the MHCCos present on the primitive Earth provided surface for the adsorption of biomonomers. These biomonomers were not only got concentrated from dilute aqueous solution, but also were protected from UV-ray degradation during the course of chemical evolution and origin of life.

\section{Acknowledgement}

Both authors (RS and AK) are thankful to MHRD for a fellowship.

\section{References}

1. Egami F (1975) Origin and early evolution of transition element enzymes. J Biochem 77: 1165-1169.

2. Kobayashi K, Ponnamperuma C (1985) Trace elements in chemical evolution, I. Orig Life Evol Biosph 16: 41-55.

3. Orgel LE (1974) Sedimentary minerals under reducing conditions. The origin of life and evolutionary biochemistry PP369-371.

4. Keefe AD, Miller SL (1996) Was ferrocyanide a prebiotic reagent? Orig Life Evol Biosph 26: 111-129.

5. Deeth RJ (2006) A theoretical rationale for the formation, structure and spin state of pentacyanochromate (II). European journal of inorganic chemistry 13: 2551-2555.

6. Hanusa TP (2006) Cyanide complexes of the transition metals. In: King RB. Encyclopedia of inorganic chemistry. (1stedn), John Wiley \& Sons Ltd, Oxford.

7. Ferlay S, Mallah T, Ouahes R, Veillet P, Verdaguer M (1995) A roomtemperature organometallic magnet based on Prussian blue. Nature 378: 701-703.

8. Sato O1, Iyoda T, Fujishima A, Hashimoto K (1996) Photoinduced Magnetization of a Cobalt-Iron Cyanide Science 272: 704-705.

9. Buschmann WE, Ensling J, Gütlich P, Miller JS (1999) Electron Transfer, Linkage Isomerization, Bulk Magnetic Order, and Spin-Glass Behavior in the Iron Hexacyanomanganate Prussian Blue Analogue. Chemistry-A European Journal 5: 3019-3028.

10. Upadhyay DN, Kolb DM (1993) Optical properties of Prussian-Bluemodified gold and platinum single-crystal electrodes. Journal of Electroanalytical Chemistry 358: 317-325.

11. Joseph J, Gomathi H, Rao GP (1997) Modification of carbon electrodes with zinc hexacyanoferrate. Journal of Electroanalytical Chemistry 43: 231-235.

12. Valsala TP, Roy SC, Shah JG, Gabriel J, Raj K, Venugopal V (2009) Removal of radioactive caesium from low level radioactive waste (LLW) streams using cobalt ferrocyanide impregnated organic anion exchanger. 166: 1148-1153.

13. Byrd H, Chapman BE, Talley CL (2013) Prussian Blue Coated Electrode as a Sensor for ElectroinactiveCations in Aqueous Solutions. Journal of Chemical Education 90: 775-777.

14. Kamaluddin, Nath M, Deopujari W, Sharma A (1990) Role of transition metal ferrocyanides(II) in chemical evolution. Origins of life and evolution of the biosphere 20:259-268.

15. Kamaluddin, Nath M, Sharma A (1994) Role of metal ferrocyanides in chemical evolution. Origins of life and evolution of the biosphere 24: 469-477.

16. Viladkar S, Agarwal R, Kamaluddin (1996) Adsorption of Adenine, Adenosine, and Adenosine Nucleotides on Nickel (II) Hexacyanoferrate (II). Bulletin of the Chemical Society of Japan 69: 95-100.

17. Alam T., Kamaluddin (2000a) Interaction of 2-amino, 3-amino and 4aminopyridines with nickel and cobalt ferrocyanides. Colloids and Surfaces A: Physicochemical and Engineering Aspects 162: 89-97.

18. Alam T1, Tarannum H, Ravi Kumar MN, Kamaluddin (2000) Adsorption and oxidation of aromatic amines by metal hexacyanoferrates(II). Talanta 51: 1097-1105. 
Citation: Rachana S, Anand Kumar, Asif Iqubal Md, Kamaluddin (2015) Role of Double Metal Cyanides in Chemical Evolution: Interaction of Ribose Nucelotides with Metal Hexacyanocobaltate(III). Astrobiol Outreach 3: 138. doi:10.4172/2332-2519.1000138

Page 9 of 9

19. Alam T1, Tarannum H, Ali SR, Kamaluddin (2002) Adsorption and oxidation of aniline and anisidine by chromium ferrocyanide. J Colloid Interface Sci 245: 251-256.

20. Ali SR, Ahmad J, Kamaluddin (2004a) Interaction of ribose nucleotides with metal ferrocyanides and its relevance in chemical evolution. Colloids and Surfaces A: Physicochemical and Engineering Aspects 236: 165-169.

21. Ali SR, Kamaluddin (2004b) The interaction of ribonucleotides with metal hexacyanochromates (III) and the relevance to chemical evolution. Bulletin of the Chemical Society of Japan 77: 1681-1686.

22. Ali SR, Kamaluddin (2006) Interaction of aromatic amino acids with metal hexacyanochromate(III) complexes: A possible role in chemical evolution. Bulletin of the Chemical Society of Japan 79: 1541-1546.

23. Kumar A1, Kamaluddin (2013) Possible role of metal(II) octacyanomolybdate(IV) in chemical evolution: interaction with ribose nucleotides. Orig Life Evol Biosph 43: 1-17.

24. Kruger K, Grabowski PJ, Zaug AJ, Sands J, Gottschling DE, et al. (1982) Self-splicing RNA: autoexcision and autocyclization of the ribosomal RNA intervening sequence of Tetrahymena. Cell 31: 147-157.

25. Gilbert W (1986) Origin of life: The RNA world. Nature 319: 618.

26. Joyce GF1 (2002) The antiquity of RNA-based evolution. Nature 418: 214-221.

27. Steitz TA1, Moore PB (2003) RNA, the first macromolecular catalyst: the ribosome is a ribozyme. Trends Biochem Sci 28: 411-418.

28. Brack A (2006) Clay minerals and the origins of life. Pp. 379-391. In: Handbook of Clay Science (F Bergaya, BKG. Theng, G Lagaly, editors), Elsevier, Amsterdam.

29. Ferris JP1, Hagan WJ Jr (1986) The adsorption and reaction of adenine nucleotides on montmorillonite. Orig Life Evol Biosph 17: 69-84.

30. Ferris JP1, Ertem G, Agarwal VK (1989) The adsorption of nucleotides and polynucleotides on montmorillonite clay. Orig Life Evol Biosph 19: 153-164.

31. Holm NG1, Ertem G, Ferris JP (1993) The binding and reactions of nucleotides and polynucleotides on iron oxide hydroxide polymorphs. Orig Life Evol Biosph 23: 195-215.

32. Hashizume H, Theng BKG (2007) Adenine, adenosine, ribose and 5'AMP adsorption to allophone. Clays and Clay Minerals 55: 599-605.

33. Feuillie C, Daniel I, Michot LJ, Pedreira-segade U (2013a) Adsorption of nucleotides onto $\mathrm{Fe}-\mathrm{Mg}-\mathrm{Al}$ rich swelling clay. GeochimicaetCosmochimicaActa 120: 97-108.

34. Feuillie C, Sverjensky DA, Hazen RM (2013b) Interaction of ribonucleotides with oxide and silicate minerals under varying environmental conditions. American geophysical Union, Fall meeting.

35. Hashizume H, Gaast van der S, Theng BKG (2013) "Interaction of clay minerals with RNA components" Evolutionary Biology, Exobiology and Evolutionary mechanisms, Springer Berlin Heidelberg, pp 61-79.
36. Georgelin T, Jaber M, Onfroy T, Hargrove AA, Costa-Torro F, et al (2013) Inorganic phosphate and nucleotides on silica surfaces: condensation, dismutation, and phosphorylation. The Journal of Physical Chemistry C 117: 12579-12590.

37. Kaye SS1, Long JR (2005) Hydrogen storage in the dehydrated prussian blue analogues $\mathrm{M} 3[\mathrm{Co}(\mathrm{CN}) 6] 2(\mathrm{M}=\mathrm{Mn}, \mathrm{Fe}, \mathrm{Co}, \mathrm{Ni}, \mathrm{Cu}, \mathrm{Zn})$. J Am Chem Soc 127: 6506-6507.

38. Martell AE, Smith RM (1974) Critical Stability Constants. (2ndedn), Plenum Press, New York.

39. Taylor RS, Diebler H (1976) Kinetic and equilibrium studies of the binding of nickel(1l) to 5'-adenosine monophosphate and related compounds. Bioinorganic Chemistry 6: 247-264.

40. Arora AK, Tomar V, Aarti, Venkateswararao KT, Kamaluddin (2007a) Hematite-water system on mars and its possible role in chemical evolution. International Journal of Astrobiology 6: 267-271.

41. Arora AK, Kamaluddin (2007b) Interaction of ribose nucleotides with zinc oxide and relevance in chemical evolution. Colloids and Surfaces A: Physicochemical and Engineering Aspects 298: 186-191.

42. Arora AK1, Kamaluddin (2009) Role of metal oxides in chemical evolution: interaction of ribose nucleotides with alumina. Astrobiology 9: 165-171.

43. Lailach GE, Thompson TD, Brindley GW (1968) Absorption of pyrimidines, purines and nucleosides by $\mathrm{Co}_{-}, \mathrm{Ni}-, \mathrm{Cu}-$, and $\mathrm{Fe}(\mathrm{III})-$ montmorillonite. Clays Clay Minerals 16: 285- 301.

44. Lawless JG1, Banin A, Church FM, Mazzurco J, Huff R, et al. (1985) pH profile of the adsorption of nucleotides onto montmorillonite. I. Selected homoionic clays. Orig Life Evol Biosph 15: 77-88.

45. Ohno SI (1967) The photochemistry of aqueous hexacyanoferrate(II) solutions. I photo-aquation reaction at 3660A. Bulletin of the Chemical Society of Japan 40: 1765-1769.

46. Widmann A, Kahlert H, Prelevic IP, Wulff H, Yakhmi JV, et al (2002) Structure, insertion electrochemistry, and magnetic properties of a new type of substitutional solid solutions of copper, nickel, and iron hexacyanoferrates/hexacyanocobaltates. Inorganic Chemistry 41: 5706-5715

47. Natesakhawat S, Culp JT, Matranga C, Bockrath B (2007) Adsorption properties of hydrogen and carbon dioxide in Prussian blue analogues $\mathrm{M} 3[\mathrm{Co}(\mathrm{CN}) 6] 2, \mathrm{M}=\mathrm{Co}, \mathrm{Zn}$. The Journal of Physical Chemistry C 111: 1055-1060.

48. Hashizume H, Gaast SV, Theng BKG (2010) Adsorption of adenine, cytosine, uracil, ribose, and phosphate by Mg-exchanged montmorillonite. Clay Minerals 45: 469-475. 